Int. J. Morphol.,

36(1):175-179, 2018

\title{
Neuroprotective Effects of Ganoderma lucidum on Spinal Cord Injury
}

\author{
Efectos Neuroprotectores de Ganoderma lucidum en la Lesión de la Médula Espinal I
}

\author{
Ekinci Aysun'; Ozevren Hüseyin²; Bilgiç Bülent Emre ${ }^{3}$; Ekinci Cenap ${ }^{4}$; Deveci Senay ${ }^{5}$ \& Deveci Engin ${ }^{4}$
}

EKINCI, A.; OZEVREN, H.; BILGIÇ, B. E.; EKINCI, C.; DEVECI, S. \& DEVECI, E. Neuroprotective effects of Ganoderma lucidum on spinal cord injury. Int. J. Morphol., 36(1):175-179, 2018.

SUMMARY: Traumatic injury to the spinal cord results in the delayed dysfunction and neuronal death. Impaired mitochondrial function, generation of reactive oxygen species (ROS), and lipid peroxidation occur soon after traumatic spinal cord injury (SCI), while the activation of compensatory molecules that neutralize ROS occurs at later time points. The aim of the current study was to investigate the putative neuroprotective effect of Ganoderma lucidum in a rat model of SCI. In order to induce SCI, a standard weight-drop method that induced a moderately severe injury (100 g/cm force) at T10, was used. Injured animals were given either $20 \mathrm{~mL} / \mathrm{kg}$ Ganoderma lucidum or saline 30 min post injury per day by gastric gavage. At seven days postinjury, rats were decapitated. Spinal cord samples were taken for histological examination or determination of malondialdehyde (MDA) and glutathione (GSH) levels, myeloperoxidase (MPO) activity. SCI caused a significant decrease in spinal cord GSH content, which was accompanied with significant increases in MDAlevels, MPO activity. On the other hand, Ganoderma lucidum treatment reversed all these biochemical parameters as well as SCI-induced histopathological alterations. Furthermore, impairment of the neurological functions due to SCI was improved by meloxicam treatment. The present study suggests that Ganoderma Lucidum, reduces SCI-induced oxidative stress and exerts neuroprotection by inhibiting lipid peroxidation, GSH depletion.

KEY WORDS: Spinal cord injury; Ganoderma lucidum; VEGF; PCNA.

\section{INTRODUCTION}

Neurologic injury caused by ischemia-reperfusion injury of the spinal cord has been a frequency between $3 \%$ and $24 \%$ (Cambria et al., 1997). Neurologic damage developing after acute spinal cord injury is related with necrosis developing after secondary injury and primary mechanic injury and apoptosis which develops later (Anderson et al., 1982). Oxygen-derived free radicals have been implicated in the pathogenesis of spinal cord neuronal injury after trauma. Decreasing the level of oxidative stress minimizes the secondary destruction effect after traumatic injury (Yazihan et al., 2008). Numerous studies reported that increased oxidative stress due to ischemia-reperfusion injury is associated with decreased enzymatic and non-enzymatic antioxidant defense potential, such as glutathione (GSH), superoxide dismutase (SOD) and catalase (CAT) activities (Naik et al., 2006; Morsy et al., 2010). Vascular endothelial growth factor (VEGF) is among the significantly upregulated genes found in SCI rats with allodynia (Nesic et al., 2005).VEGF isoforms play important roles in the development of vascular network, it independently works on neuron to guide neurogenesis (Jin et al. (2002), axon growth (Sondell et al., 1999; Alitalo et al., 2011; Erskine et al., 2011; Ruiz de Almodovar et al. 2011) Nuclear Antigen (PCNA) is a significant cell-cycle regulated nuclear protein for DNApolymerase, the PCNA-labeled nuclei had been shown to identify cells in the late G1 and early S phases of the cell cycle, as well as cells undergoing DNA repair (Chen et al., 2005). Oral administration of Ganoderma lucidum has been shown to significantly reduce both cerebral infarct area and neuronal apoptosis in the ischemic cortex (Zhou et al., 2012). Recent studies have demonstrated the neuroprotective effect of Ganoderma lucidum to reduce oxidative stress in vitro (Zhao et al., 2005), to induce neuronal differentiation (Cheung et al., 2000), and to prevent the harmful effects of the exterminating toxin $\mathrm{Ab}$ in Alzheimer's disease in cultured rat neurons (Lai et al., 2008). In this study. The protective effect of Ganoderma lucidum on neuronal and angiogenetic function after medulla spinalis injury was investigated.

\footnotetext{
${ }^{1}$ Department of Biochemistry, Dicle University School of Medicine, Diyarbakir, Turkey.

${ }^{2}$ Departments of Neurosurgery, Dicle University School of Medicine, Diyarbakir, Turkey.

${ }^{3}$ Department of Histology and Embryology, Zeynep Kamil Hospital,Istanbul, Turkey.

${ }^{4}$ Department of Histology and Embryology, Dicle University School of Medicine, Diyarbakir, Turkey.

${ }^{5}$ Ataturk Health High School, Dicle University, Diyarbakir, Turkey.
} 


\section{MATERIAL AND METHOD}

The investigation was conducted in accordance with the Guide for the Care and Use of Laboratory Animals published by US National Institutes of Health $(\mathrm{NIH}$ Publication no. 85-23, revised 1996). All experimental protocols were approved by the Dicle University Animal Care and Use Committee. Male Sprague-Dawley rats (200$230 \mathrm{~g}$ ) were housed in an air-conditioned room with 12-h light and dark cycles, where the temperature $\left(23 \pm 2{ }^{\circ} \mathrm{C}\right)$ and relative humidity $(65-70 \%)$ were kept constant.

Anesthetized (ip ketamine and chlorpromazine; 75 $\mathrm{mg} / \mathrm{kg}$ and $1 \mathrm{mg} / \mathrm{kg}$, respectively) rats were positioned on a heating pad in a prone position and a rectal probe was inserted. Under sterile conditions, following T5-12 midline skin incision and paravertebral muscle dissection, spinous processes and laminar arcs of T7-10 were removed. The dura was left intact. Weight-drop model was performed for SCI (Allen, 1911). The animals were subjected to an impact of $100 \mathrm{~g} / \mathrm{cm}$ to the dorsal surface of the spinal cord. The force was applied via a stainless steel rod (3 $\mathrm{mm}$ diameter tip weighing $10 \mathrm{~g}$ ) that was rounded at the surface. The rod was dropped vertically through a $10-\mathrm{cm}$ guide tube that was positioned perpendicular to the center of the spinal cord. Afterward, the muscles and the incision were sutured. Following surgical procedure, the rats were placed in warming chamber and their body temperatures were maintained at approximately $37^{\circ} \mathrm{C}$ until they were completely awake. Thirty minutes after the spinal cord injury, rats were injected either saline or G. lucidum polysaccharides (GLPS) $(400 \mathrm{mg} / \mathrm{kg} /$ day) via gastric gavage. The seventh day all 30 animals were killed after TBI. Thirty rats were divided into three groups as group 1 control group, 2 spinal cord injury group, 3 spinal cord injury + Gonoderma lucidum group (20 $\mathrm{mL} / \mathrm{kg}$ per day via gastric gavage) Ganoderma lucidum was administered for 7 days after trauma. Each group consisted of 10 animals, and of these, six were used for biochemical (Table I) and the other four were used for the evaluation of histological analysis.
Histological Preparation and Analysis. At the end of the experiment, all animals were anesthetized via the intraperitoneal administration of ketamine HCL $(0.15 \mathrm{ml} /$ $100 \mathrm{~g}$ body weight). The cerebellum were dissected. For the histological examination, cerebellum tissues were fixed in $10 \%$ formaldehyde solution, post fixed in $70 \%$ alcohol, and embedded in paraffin wax. The sections were stained with Hematoxylin-Eosin

Immunohistochemical staining. An antigen-retrieval process was performed in citrate buffer solution ( $\mathrm{pH}$ 6.0) two times: first for $7 \mathrm{~min}$, and then for $5 \mathrm{~min}$ in a microwave oven at $700 \mathrm{~W}$. They were allowed to cool to room temperature for $30 \mathrm{~min}$ and washed in distilled water for 5 min twice. Endogenous peroxidase activity was blocked in $0.1 \%$ hydrogen peroxide for 15 min. Ultra $\mathrm{V}$ block (Histostain-Plus Kit, Invitrogen, Carlsbad, CA) was applied for $10 \mathrm{~min}$ prior to the application of the primary antibodies (VEGF antibody, mouse monoclonal, 1/200, Santa Cruz Biotechnology) overnight.

The secondary antibody (Histostain-Plus Kit, Invitrogen, Carlsbad, CA) was applied for $20 \mathrm{~min}$. Then the slides were exposed to streptavidin-peroxidase for 20 min. Diaminobenzidine (DAB, Invitrogen, Carlsbad) was used as a chromogen. Control slides were prepared as mentioned above but omitting the primary antibodies. After counterstaining with Hematoxylene, washing in tap water for $5 \mathrm{~min}$, and in distilled water for $2 ¥ 5 \mathrm{~min}$, the slides were mounted.

Tunnel technique. Anti-proliferating cell nuclear antigen (PCNA) antibody was employed for detection of the proliferation rate of enterocytes. Sections taken to distilled water were then washed in PBS $2 \times 5$ min sections were kept in freshly prepared permeabilization solution $(0.1 \%$ Triton X-100 in $0.1 \%$ sodium citrate) 8 min on ice. then washed in PBS $2 \times 5$ min and Added TUNEL Mixture (diluted 1:1 with TUNEL Dilution Buffer) on sections in the dark in humidified chamber for 1 at $37^{\circ} \mathrm{C}$. They were subsequently washed in PBS $2 \times 5$ min, As a substrate

Table I. Biochemical results relevant to the study groups.

\begin{tabular}{lcccc}
\hline & \multicolumn{1}{c}{ Control } & G. lucidum & \multicolumn{1}{c}{ Trauma } & Trauma + G. lucidum \\
\hline MDA $(\mathrm{nmol} / \mathrm{g})$ & $26.75 \pm 0.85$ & $26.23 \pm 0.88$ & $43.95 \pm 0.77^{* * *}$ & $29.38 \pm 0.87^{+++}$ \\
GSH $(\mu \mathrm{mol} / \mathrm{g})$ & $1.58 \pm 0.04$ & $1.60 \pm 0.03^{*}$ & $0.75 \pm 0.06^{* * *}$ & $1.41 \pm 0.04^{+++}$ \\
MPO $(\mathrm{U} / \mathrm{g})$ & $3.47 \pm 0.05$ & $3.49 \pm 0.04$ & $7.44 \pm 0.62^{* * *}$ & $6.75 \pm 0.49^{++}$ \\
\hline
\end{tabular}

Values are represented as mean $\pm \mathrm{SD}$. Each group consists of sixteen rats.

$* \mathrm{p}<0.05$, versus control. $* * * \mathrm{p}<0.001$, versus control. $\quad++\mathrm{p}<0.01$, trauma + G. lucidum versus trauma. $+++\mathrm{p}<0.001$, trauma + G. lucidum versus trauma 
solution, Fast Red (Roche) was applied on sections. Sections were counterstained with Hematoxyline, Mounted with Kaiser's Glycerol Gelatine (Roche).

Measurement of MPO Activity. MPO activity in tissues was measured by a procedure similar to that described by Hillegass et al. (1990).Spinal cord tissue samples were homogenized in $50 \mathrm{mM}$ potassium phosphate buffer with a pH of 6.0, and centrifuged at $41,400 \mathrm{~g}$ for $10 \mathrm{~min}$. The pellets were then suspended in $50 \mathrm{mM}$ PB containing 0.5 $\%$ hexa-decyl trimethyl-ammonium bromide (HETAB). After three freeze and thaw cycles, with sonication between cycles, the samples were centrifuged at $41,400 \mathrm{~g}$ for 10 min. Aliquots $(0.3 \mathrm{ml})$ were added to $2.3 \mathrm{ml}$ of reaction mixture containing $50 \mathrm{mM} \mathrm{PB}$, o-dianisidine, and $20 \mathrm{mM}$ $\mathrm{H}_{2} \mathrm{O}_{2}$ solution. One unit of enzyme activity was defined as the amount of MPO present that caused a change in absorbance, measured at $460 \mathrm{~nm}$ for $3 \mathrm{~min}$. MPO activity was expressed as U/g tissue.

Malondialdehyde (MDA) and Glutathione (GSH) Assays. Spinal cord tissue samples were homogenized with ice-cold $150 \mathrm{mMKCl}$ for the determination of MDA and GSH levels. The MDA levels were assayed for the products of lipid peroxidation and results are expressed as nmol MDA/g tissue (Buege \& Aust, 1978), GSH was determined by a spectrophotometric method based on the use of Ellman's reagent and results are expressed as mmol GSH/ g tissue (Beutler et al., 1963).

Statistical Analysis. All data are expressed as means \pm S.D. Groups of data were compared with an analysis of variance (ANOVA) followed by Tukey's multiple comparison tests. Values of $\mathrm{p}<0.05$ were considered as significant.

\section{RESULTS AND DISCUSSION}

MPO activity, which is accepted as an indicator of neutrophil infiltration, was significantly higher in the spinal cord tissues of traumatic rats than those of the control group $(\mathrm{p}<0.001)$. Ganoderma treatment significantly decreased spinal cord tissue MPO levels ( $\mathrm{p}<0.01)$. (Tabla I and Fig. 1)

Trauma caused a significant increase in the MDA levels $(p<0.001)$ with a concomitant decrease in GSH levels $(p<0.001)$. Ganoderma treatment significantly reduced the increase in MDA levels and restored GSH content at seventh day.

Spinal cord trauma results in a rapid and extensive oxidative stress. It has long been established that oxidative stress plays a critical role in the pathophysiology of SCI (Christie et al., 2008; DeRuisseau et al., 2009; Savas et al., 2009).

G. lucidum extract reduced the expressions of proinflammatory and cytotoxic factors from the activated microglia, and effectively protected the dopaminergic neurons against inflammatory and oxidative damage (Huang et al., 2010). Some studies have shown that administration of VEGF to the injured spinal cord has neuroprotective effects, induces angiogenesis and improves neurobehavioral results (Widenfalk et al., 2003; Patel et al., 2009; Liu et al., 2010). Our data show that VEGF expression is increased in spinal cord injury, but VEGF expression in neuron and endothelial cells is decreased in spinal cord injury of Ganoderma lucidum treatment.Vascular endothelial growth factor (VEGF), angiogenesis and vascularization of spinal cord injury (SCI) are important contributors. VEGF is thought to be an important neurotrophic for the continuity of spinal cord neurons and endothelial cells.(Fig. 2)
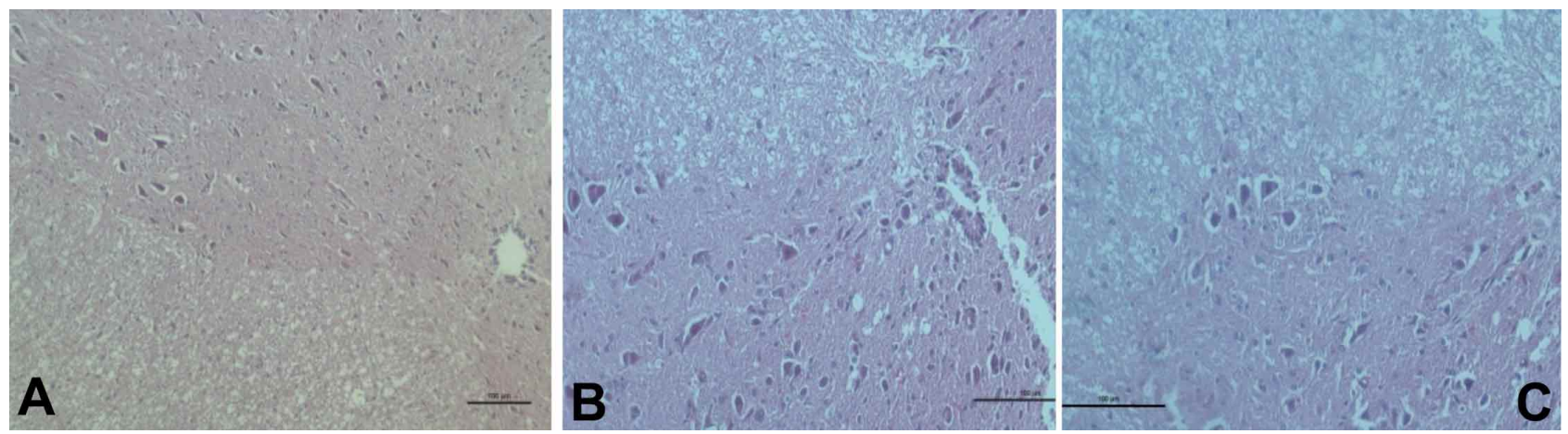

Fig. 1. A. Control group: Canalis ependimalis covered with oval nucleus cubic-shaped epithelium, multipolar and bipolar neuron structures and glial cells in the Cornu anterior region were regularly observed. H-E staining Bar $100 \mathrm{~mm}$. B. Spinal cord injury group: Degeneration and loss in Kanalis ependimalis cells, deterioration in some radical cells, hyperplasia in funicular cells, dilation in small capillary vessels, vacuolar structures in the area of substantia grisea were observed.HE staining Bar $100 \mathrm{~mm}$. C. Spinal cord injury group+Ganoderma lucidum group: Mild degeneration in radicular cells, hyperplasia in funicular cells, vascular dilatation and reduction of vacuolar structures in the substantia grisea region. H-E staining Bar $100 \mathrm{~mm}$. 
Reactive astrocytes also play a crucial role in wound healing and functional recovery after SCI. At the subacute phase, astrocytes migrate to compact the lesion, presumably secluding the inflammatory cells to prevent them from spreading into the parenchyma of the spinal cord (Okada et al. 2006). Xiangdong et al.. observed that PCNA expression in astrocytes increased in white matter after spinal cord injury. In our study, the expression of astrocytes in PCNA and white matter increased in the nuclei of glial cells in radicular and funicular cells. In spinal cord injury, it was observed that the DNA structure changed and caused apoptotic changes. PCNA expression in the ganoderma group showed a weak reaction in the gray matter and white matter, and DNA and apoptotic changes in the nucleus structure decreased. Ganoderma lucidum, an antioxidant effective dose and duration dependent inhibitor of cell apoptosis and altered angiogenetic activity, has been implicated in changes in neurons and glial cells in spinal cord injury and in angiogenesis, impairing its dose and duration.
EKINCI, A.; OZEVREN, H.; BILGIÇ, B. E.; EKINCI, C.; DEVECI, S. \& DEVECI, E. Efectos Neuroprotectores de Ganoderma lucidum sobre la lesión de la médula espinal. Int. J. Morphol., 36(1):175-179, 2018.

RESUMEN: La lesión traumática de la médula espinal provoca disfunción retrasada y muerte neuronal. La función mitocondrial deteriorada, la generación de especies reactivas de oxígeno (ERO) y la peroxidación lipídica ocurren poco después de una lesión traumática de la médula espinal (LTE), mientras que la activación de moléculas compensatorias que neutralizan ERO ocurre posteriormente. El objetivo del presente estudio fue investigar el efecto neuroprotector de Ganoderma lucidum en un modelo de LTE en ratas. Con el fin de inducir LTE, se utilizó un método estándar de pérdida de peso que indujo una lesión moderadamente grave (100 g / cm de fuerza) a T10. A los animales lesionados se les administró $20 \mathrm{ml} / \mathrm{kg}$ de Ganoderma lucidum o solución salina, por sonda gástrica, 30 minutos después de la lesión. A los siete días después de la lesión, las ratas fueron eutanasiadas por decapitación. Se tomaron muestras de médula espinal para el examen histológico y para la determinación de los niveles de malondialdehído (MDA) y glutatión (GSH), y la actividad de mieloperoxidasa (MPO). LTE causó una disminución
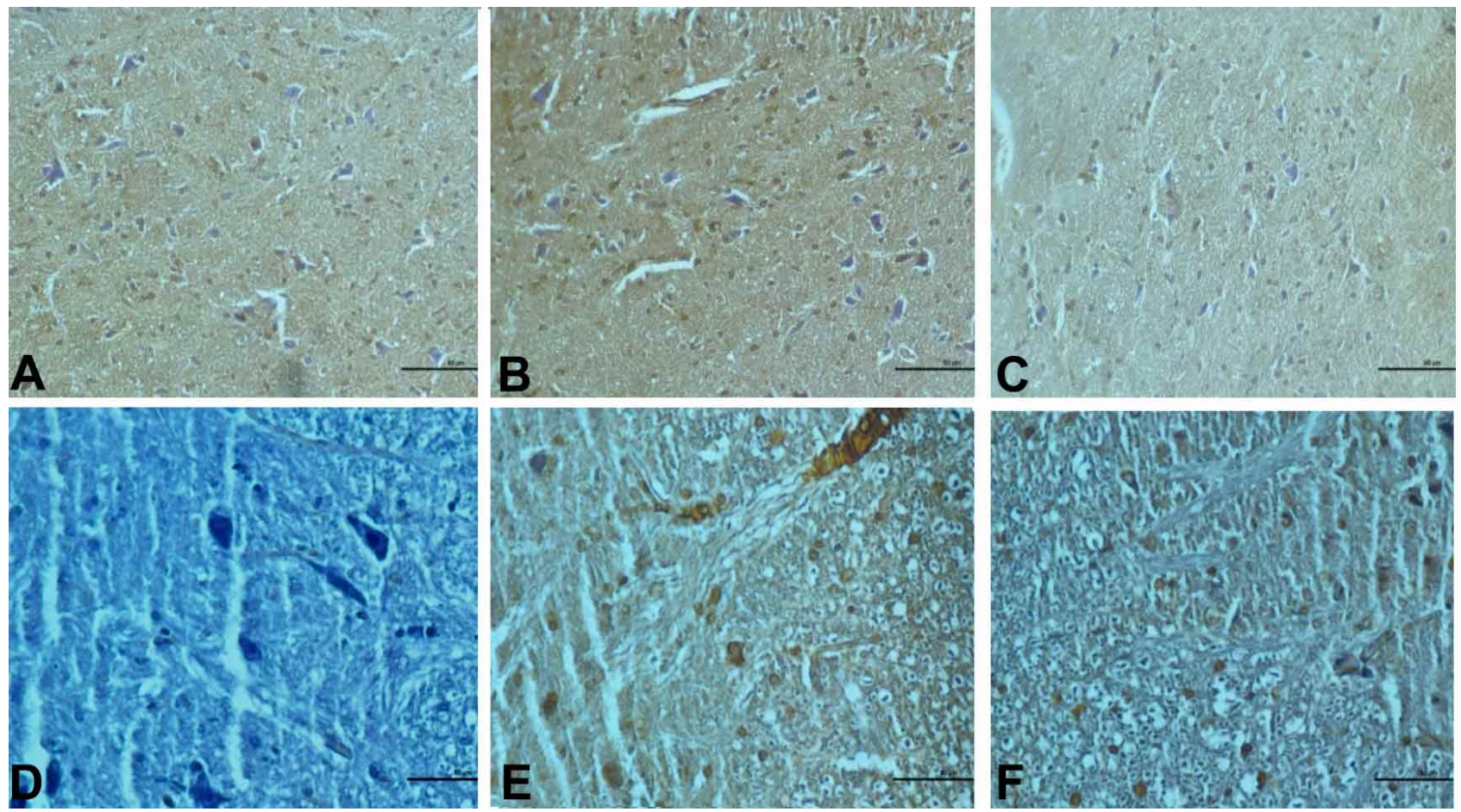

Fig. 2. A.Control group: Negative VEGF expression in radicular and funicular cells, VEGF expression in glia cells and vascular endothelium was weakly observed.VEGF immunostaining staining Bar $100 \mu \mathrm{m}$; B. Spinal cord injury group:Positive VEGF expression was observed in Glia cells and vascular endothelial cells.VEGF immunostaining staining Bar 100 $\mu \mathrm{m}$; C. Spinal cord injury group+Ganoderma lucidum group: In multipolar and bipolar neurons, weak VEGF expression was seen in glial cells and vascular endothelial cells. VEGF immunostaining staining Bar $100 \mu \mathrm{m}$; D. Control group: Negative PCNA expression in the radicular and funicular cells and glial cells. PCNA immunostaining Bar $50 \mu \mathrm{m}$; E. Spinal cord injury group: In radicular and funicular cells, the expression of PCNA in the nucleus of the glial cells and astrocytes in white matter was increased. PCNA immunostaining staining Bar 50 $\mu$ m; F. Spinal cord injury group+Ganoderma lucidum group: In the radicular and funicular cells, the PCNA expressions in the nucleus structure of the glial cells were weakened PCNA immunostaining staining Bar $50 \mu \mathrm{m}$. 
significativa en el contenido de GSH de la médula espinal, además de aumentos significativos en los niveles de MDA y la actividad de MPO. Por otro lado, el tratamiento con Ganoderma lucidum invirtió todos estos parámetros bioquímicos así como las alteraciones histopatológicas inducidas por LTE. El deterioro de las funciones neurológicas debidas a LTE mejoró con el tratamiento con meloxicam. El presente estudio sugiere que Ganoderma lucidum, reduce el estrés oxidativo inducido por LTE y ejerce la neuroprotección mediante la inhibición de la peroxidación de los lípidos y agotamiento del GSH.

PALABRAS CLAVE: Lesión medula espinal; Ganoderma lucidum; Factor de crecimiento vascular endotelial.

\section{REFERENCES}

Allen, A. R. Surgery of experimental lesion of spinal cord equivalent to crush injury of fracture dislocation of spinal column. A preliminary report. JAMA, 57(11):878-80, 1911.

Anderson, D. K.; Means, E. D.; Waters, T. R. \& Green, E. S. Microvascular perfusion and metabolism in injured spinal cord after methylprednisolone treatment. J. Neurosurg., 56(1):106-13, 1982.

Beutler, E.; Duron, O. \& Kelly, B. M. Improved method for the determination of blood glutathione. J. Lab. Clin. Med., 61:882-8, 1963.

Buege, J. A. \& Aust, S. D. Microsomal lipid peroxidation. Methods Enzymol., 52:302-10, 1978.

Cambria, R. P.; Davison, J. K.; Zannetti, S.; L'Italien, G.; Brewster, D. C.; Gertler, J. P.; Moncure, A. C.; LaMuraglia, G. M. \& Abbott, W. M. Clinical experience with epidural cooling for spinal cord protection during thoracic and thoracoabdominal aneurysm repair. J. Vasc. Surg., 25(2):234-41, 1997.

Chen, W.; Fu, X. B.; Ge, S. L.; Sun, T. Z.; Li, W. J. \& Shen, Z. Y. Acid fibroblast growth factor reduces rat intestinal mucosal damage caused by ischemia-reperfusion insult. World J. Gastroenterol., 11(41):6477-82, 2005 .

Cheung, W. M.; Hui, W. S.; Chu, P. W.; Chiu, S. W. \& Ip, N. Y. Ganoderma extract activates MAP kinases and induces the neuronal differentiation of rat pheochromocytoma PC12 cells. FEBS Lett., 486(3):291-6, 2000.

Christie, S. D.; Comeau, B.; Myers, T.; Sadi, D.; Purdy, M. \& Mendez, I. Duration of lipid peroxidation after acute spinal cord injury in rats and the effect of methylprednisolone. Neurosurg. Focus, 25(5):E5, 2008.

DeRuisseau, L. R.; Recca, D. M.; Mogle, J. A.; Zoccolillo, M. \& DeRuisseau, K. C. Metallothionein deficiency leads to soleus muscle contractile dysfunction following acute spinal cord injury in mice. Am. J. Physiol. Regul. Integr. Comp. Physiol., 297(6):R1795-802, 2009.

Erskine, L.; Reijntjes, S.; Pratt, T.; Denti, L.; Schwarz, Q.; Vieira, J. M.; Alakakone, B.; Shewan, D. \& Ruhrberg, C. VEGF signaling through neuropilin 1 guides commissural axon crossing at the optic chiasm. Neuron, 70(5):951-65, 2011.

Hillegass, L. M.; Griswold, D. E.; Brickson, B. \& Albrightson-Winslow, C. Assessment of myeloperoxidase activity in whole rat kidney. $J$. Pharmacol. Methods, 24(4):285-95, 1990.

Huang, S. Q.; Li, J. W.; Wang, Z.; Pan, H. X.; Chen, J. X. \& Ning, Z. X. Optimization of alkaline extraction of polysaccharides from Ganoderma lucidum and their effect on immune function in mice. Molecules, 15(5):3694-708, 2010.

Jin, K.; Zhu, Y.; Sun, Y.; Mao, X. O.; Xie, L. \& Greenberg, D. A. Vascular endothelial growth factor (VEGF) stimulates neurogenesis in vitro and in vivo. Proc. Natl. Acad. Sci. U. S. A., 99(18):11946-50, 2002.

Lai, C. S.; Yu, M. S.; Yuen, W. H.; So, K. F.; Zee, S. Y. \& Chang, R. C. Antagonizing beta-amyloid peptide neurotoxicity of the anti-aging fungus Ganoderma lucidum. Brain Res., 1190:215-24, 2008.

Liu, Y.; Figley, S.; Spratt, S. K.; Lee, G.; Ando, D.; Surosky, R. \& Fehlings,
M. G. An engineered transcription factor which activates VEGF-A enhances recovery after spinal cord injury. Neurobiol. Dis., 37(2):38493, 2010.

Morsy, M. D.; Mostafa, O. A. \& Hassan, W. N. A potential protective effect of alpha-tocopherol on vascular complication in spinal cord reperfusion injury in rats. J. Biomed. Sci., 17:55, 2010.

Naik, A. K.; Tandan, S. K.; Dudhgaonkar, S. P.; Jadhav, S. H.; Kataria, M.; Prakash, V. R. \& Kumar, D. Role of oxidative stress in pathophysiology of peripheral neuropathy and modulation by $\mathrm{N}$-acetyl-L-cysteine in rats. Eur. J. Pain, 10(7):573-9, 2006.

Nesic, O.; Lee, J.; Johnson, K. M.; Ye, Z.; Xu, G. Y.; Unabia, G. C.; Wood, T. G.; McAdoo, D. J.; Westlund, K. N.; Hulsebosch, C. E. \& Regino PerezPolo, J. Transcriptional profiling of spinal cord injury-induced central neuropathic pain. J. Neurochem., 95(4):998-1014, 2005.

Okada, S.; Nakamura, M.; Katoh, H.; Miyao, T.; Shimazaki, T.; Ishii, K.; Yamane, J.; Yoshimura, A.; Iwamoto, Y.; Toyama, Y. \& Okano, H. Conditional ablation of Stat 3 or Socs 3 discloses a dual role for reactive astrocytes after spinal cord injury. Nat. Med., 12(7):829-34, 2006.

Patel, C. B.; Cohen, D. M.; Ahobila-Vajjula, P.; Sundberg, L. M.; Chacko, T. \& Narayana, P. A. Effect of VEGF treatment on the blood-spinal cord barrier permeability in experimental spinal cord injury: dynamic contrastenhanced magnetic resonance imaging. J. Neurotrauma, 26(7):1005-16, 2009.

Ruiz de Almodovar, C.; Fabre, P. J.; Knevels, E.; Coulon, C.; Segura, I.; Haddick, P. C.; Aerts, L.; Delattin, N.; Strasser, G.; Oh, W. J.; Lange, C.; Vinckier, S.; Haigh, J.; Fouquet, C.; Gu, C.; Alitalo, K.; Castellani, V.; Tessier-Lavigne, M.; Chedotal, A.; Charron, F. \& Carmeliet, P. VEGF mediates commissural axon chemoattraction through its receptor Flk1. Neuron, 70(5):966-78, 2011.

Savas, M.; Verit, A.; Ciftci, H.; Yeni, E.; Aktan, E.; Topal, U. \& Erel, O. Oxidative stress in BPH. J. N. M. A. J. Nepal Med. Assoc., 48(173):41-5, 2009.

Sondell, M.; Lundborg, G. \& Kanje, M. Vascular endothelial growth factor has neurotrophic activity and stimulates axonal outgrowth, enhancing cell survival and Schwann cell proliferation in the peripheral nervous system. J. Neurosci., 19(14):5731-40, 1999.

Widenfalk, J.; Lipson, A.; Jubran, M.; Hofstetter, C.; Ebendal, T.; Cao, Y. \& Olson, L. Vascular endothelial growth factor improves functional outcome and decreases secondary degeneration in experimental spinal cord contusion injury. Neuroscience, 120(4):951-60, 2003.

Yazihan, N.; Uzuner, K.; Salman, B.; Vural, M.; Koken, T. \& Arslantas, A. Erythropoietin improves oxidative stress following spinal cord trauma in rats. Injury, 39(12):1408-13, 2008.

Zhao, H. B.; Wang, S. Z.; He, Q. H.; Yuan, L.; Chen, A. F. \& Lin, Z. B. Ganoderma total sterol (GS) and GS1 protect rat cerebral cortical neurons from hypoxia/reoxygenation injury. Life Sci., 76(9):1027-37, 2005.

Zhou, Y.; Qu, Z. Q.; Zeng, Y. S.; Lin, Y. K.; Li, Y.; Chung, P.; Wong, R. \& Hägg, U. Neuroprotective effect of preadministration with Ganoderma lucidum spore on rat hippocampus. Exp. Toxicol. Pathol., 64(7-8):67380, 2012.

\section{Corresponding author:}

Dr. Engin Deveci

Department of Histology and Embryology

Dicle University Faculty of Medicine

Diyarbakır

TURKEY

Email: engindeveci64@gmail.com

Received: 01-05-2017

Accepted: 19-07-2017 